\title{
Development of Dynamometer Based on Strain Gauge with Sensor Rod Type Four Square Stalk to Measuring the Drive Power of Rotary Friction Welding Machine
}

\author{
Yohanes, ${ }^{\mathrm{a},{ }^{*}}$ and Muhammad Rahdiyat Alqolbi, ${ }^{\mathrm{b}}$ \\ a) Mechanical Engineering Departement, Universitas Riau, Indonesia \\ b) Laboratory of Technology Production, Mechanical Engineering Departement, Universitas Riau, Indonesia \\ * Corresponding author(s): yohanes@lecturer.unri.ac.id, muhammad.rahdiyatalqolbi@student.unri.ac.id
}

\section{Paper History}

Received: 13-January-2020

Received in revised form: 11-February 2020

Accepted: 30-March-2020

\begin{abstract}
Friction welding is a type of solid state welding where the welding process is carried out in the solid phase. In the welding process there are several components that work, namely the electric motor as the main mover. This study aims to developmant a dynamometer to measure the mechanical power of a rotary friction welding machine. Dynamometer development includes the design, manufacture, calibration and testing of dynamometers. Dynamometer design that will be placed on the holder that serves as a stretch bar. Dimension of the strain dynamometer is $35 \mathrm{~mm} \times$ $4 \mathrm{~mm} \times 70 \mathrm{~mm}$ and serves to determine the motor torque value with the help of a $120 \mathrm{Ohm}$ strain gauge sensor and to measure power it needs an additional speed sensor or optocoupler sensor to measure the motor angular speed. In need of making a microcontroller or an electrical device. Finally, the dynamometer testing process on a rotary friction welding machine. When the welding process takes place, the greater the pneumatic pressure exerted during welding, the more measurable the power is. The largest power value measured in the forging phase is 2408.50 Watts and the smallest power measured by the dynamometer is 2050.24 Watts at the initial rotation.
\end{abstract}

KEY WORDS: Friction Welding Machine, Mechanical Power, Dynamometer.

\section{NOMENCLATURE}

$\begin{array}{ll}\mathrm{P} & \text { Power (Watt) } \\ \mathrm{T} & \text { Torque }(\mathrm{N} . \mathrm{m}) \\ \omega & \text { The Enguler Velocity }(\mathrm{rad} / \mathrm{s}) \\ \mathrm{n} & \text { Rotational Speed }(\mathrm{rpm}) \\ \mathrm{v} & \text { V-belt Speed }(\mathrm{m} / \mathrm{s}) \\ \mathrm{c} & \text { Distance Between Pulleys }(\mathrm{mm}) \\ \mathrm{L} & \text { Belt circumference }(\mathrm{mm}) \\ \mathrm{D}_{\mathrm{p}} & \text { Pulley Diameter Driven }(\mathrm{mm}) \\ \mathrm{d}_{\mathrm{p}} & \text { Drive Pulse Diameter }(\mathrm{mm}) \\ \mathrm{w} & \text { Weight }(\mathrm{N}) \\ \mathrm{g} & \text { Acceleration of Gravity }\left(\mathrm{m} / \mathrm{s}^{2}\right) \\ \sigma & \text { Tensile Strain }\left(\mathrm{N} / \mathrm{mm}^{2}\right) \\ \mathrm{A} & \text { Belt Cross-sectional Area }\left(\mathrm{mm}^{2}\right) \\ \mathrm{F}_{\mathrm{a}} & \text { Tensile Pull Belt }(\mathrm{N}) \\ \mathrm{F}_{\mathrm{b}} & \text { Belt Slack Strain }(\mathrm{N})\end{array}$

\subsection{INTRODUCTION}

Friction welding is a welding technique using heat generated from friction. The surface of the two materials to be joined, one rotates while the other is still and pressured slowly until it reaches a melting temperature so the welding process takes place. Rotary friction welding machine in the Production Process Technology Laboratory of the Department of Mechanical Engineering, Riau University is the result of the design of Khan, M. A and Alhadi, R. (2014) [1]. Furthermore, the rotary friction welding machine was developed to optimize the friction welding again in several components by using the Faut Tree Analysis and Design for Manufacturing and Assembly (DFMA) method by Ricky and Yohanes. (2015) [2]. Some research has been done on the machine by Yohanes and P. Partomuan. (2016) [3] by varying the shape of the surface of the rotary friction joint forging against the tensile strength of mild steel, it was found that some welding 
failed during the welding process. During the research carried out electric motors often experience shock loads from the friction phase to the forging phase. So to solve this problem, Yohanes and E. Siregar. (2017) [4] conducted an experimental study of the effect of the addition of flywheel on the rotary friction welding machine to welding results which aimed to obtain a more stable engine speed and several further studies Sandri, D. E and Yohanes. 2018 [5] conducts an experimental study of the Effect of Addition of Flywheel to a Rotary Friction Welding Machine Against Welding Results of Mild Steel Material with Stainless Steel 201.

The study was continued by Yohanes and M. Efriyansyah. 2018 [6] by varying the angle of the chamfer forging against the welding strength in mild steel material. In this study, it is known how much electrical power occurs during the initial welding phase until the forging phase that can be seen on Arduino Uno installed on a computer. However, it still needs to be developed, namely the need to know how much mechanical power during the forging process until the welding phase ends. Then need a dynamometer measuring device that serves to read the magnitude of changes in distance dimensions caused by an element of force at an affordable price. The aim of this research is to design and make a stretch bar with four square stalk type as a stretch bar and to make an electrical chain that is able to measure the mechanical power of a rotary friction welding machine.

\subsection{FUNDAMENTAL THEORY}

\subsection{Rotary Friction Welding Machine}

Rotary friction welding is welding solid-state without using filler metal by using the pressure method where two workpieces which will be connected are placed in contact and arranged relative motion under pressure, then friction will generate heat around the contact surface, when it has reached the forging temperature then given forging pressure [7].

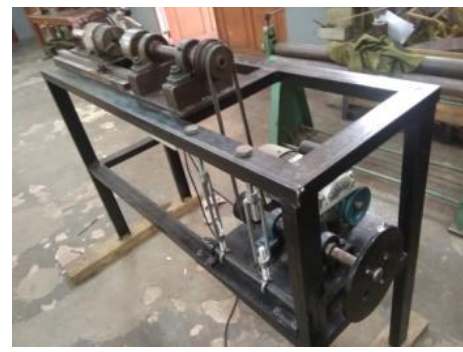

Figure 1: Rotary Friction welding Machine.

\subsection{Measurement System}

Measurement is the determination of the size, dimension, or capacity usually to a standard or unit of measure. The existence of several physical variables such as strength, temperature and others. The magnitude or strength can not be detected or measured directly, but can be known by its effect alone. For example, a power that can be seen but can be detected and also calculated respectively by its effect and the amount of such effects (materials) such as elastic, deflection, deformation, pressure, voltage and others [8].

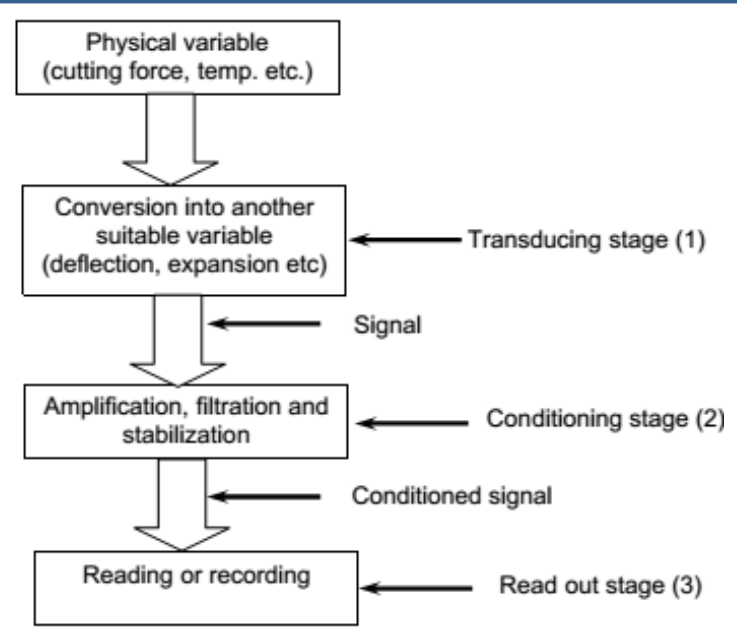

Figure 2: Basic Methods and General Measurement Principles (Indians 2011)

\subsection{Motor Power}

The electric motor functions as the main driving source of the shaft. The required motor power can be determined by the following equation (Sularso, and Suga, K. 1997) [9].

$$
P=T . \omega
$$

By calculating torque with the following equation [9].

$$
\mathrm{T}=\frac{P}{n}
$$

Meanwhile, to calculate the angular velocity using the following substitution equation [9].

$$
\omega=\frac{2 \pi n}{60}
$$

\subsection{Strain gauge}

Strain Gauge is used to detect the magnitude of changes in distance dimensions caused by a force element. Strain Gauge is commonly used in measuring precision of force, weight, pressure, torque, displacement and other mechanical quantities [10].

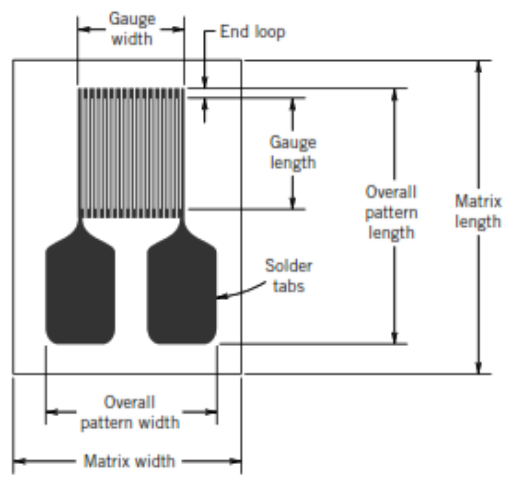

Figure 3: Strain gauge (Figliola, R.S. dan. D.E. Beasley. 2011). 


\subsection{Wheatstone Bridge}

The Wheatstone Bridge is used to obtain accuracy in evaluating relatively small prisoners. This circuit is formed by four resistors (R) which are quadrilateral A-B-C-D in which case the circuit is connected to a voltage source [10].
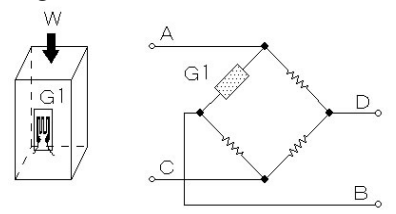

Figure 4: Wheatstone Bridge.

\subsection{Module HX-711}

The HX711 is a weighing module that has the working principle of amplifying the measured voltage changes in the strain gauge sensor and converting it into electrical quantities through the existing circuit.

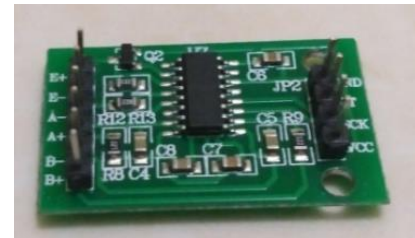

Figure 5: Module HX-711.

\subsection{Arduino UNO}

This arduino is a microcontroller board based on ATmega328. Arduino UNO contains everything needed to support the microcontroller, easily connect it to a computer with a USB cable or supply it with an AC adapter to DC or use the battery to start it. ATmega328 on Arduino Uno comes with a bootloader that allows us to upload new code to ATmega328 without using an external hardware programmer [11].

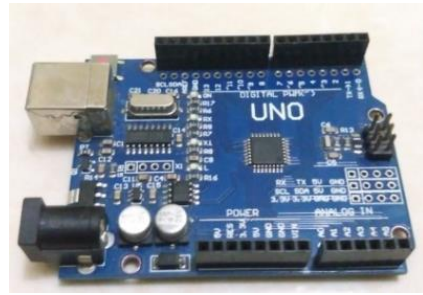

Figure 6: Arduino UNO.

\subsection{Chop Wheel}

The chopping wheel is a circular paper that functions to calculate the speed of the motor's turning angle (rpm).

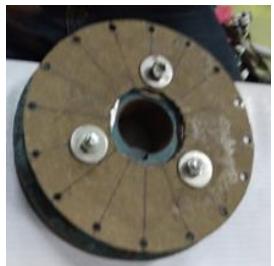

Figure 7: Chop Wheel

\subsection{Optocoupler Sensor}

Speed sensor is a sensor used to read the rotation of an electric motor when rotating on a rotary friction welding machine.



Figure 8: Optocoupler Sensor

\subsection{LCD (Liquid Cristal Display)}

According to (Lingga, W. 2006). LCD (Liquid Crystal Display) Display $16 \times 2$ serves as a character viewer in the input through the keypad. LCD used in this tool has a display width of 2 lines 16 columns or commonly referred to as LCD Character $16 \times 2$, with 16 pin connector [12].



Figure 9: LCD

\subsection{Data Logger}

Data logger is an electronic device that functions to record data from test results.

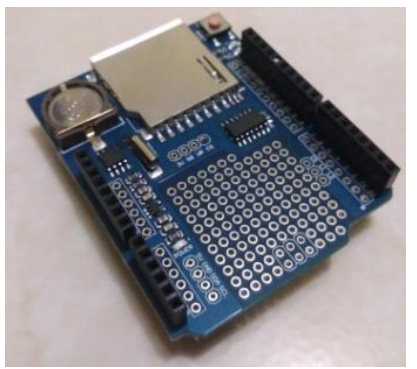

Figure 10: Data Logger

\subsection{Stres and Strain}

In general, the strain that occurs can be formulated as follows. (Sularso, and Suga, K. 1997) [9].

$$
\epsilon=\frac{\Delta L}{L}
$$

Any material that is stressed will cause tension which is perpendicular to the cutting plane and cross-sectional area. In general, the stress formula is as follows [9].

$$
\sigma=\frac{F}{A}
$$




\subsection{METHODOLOGY}

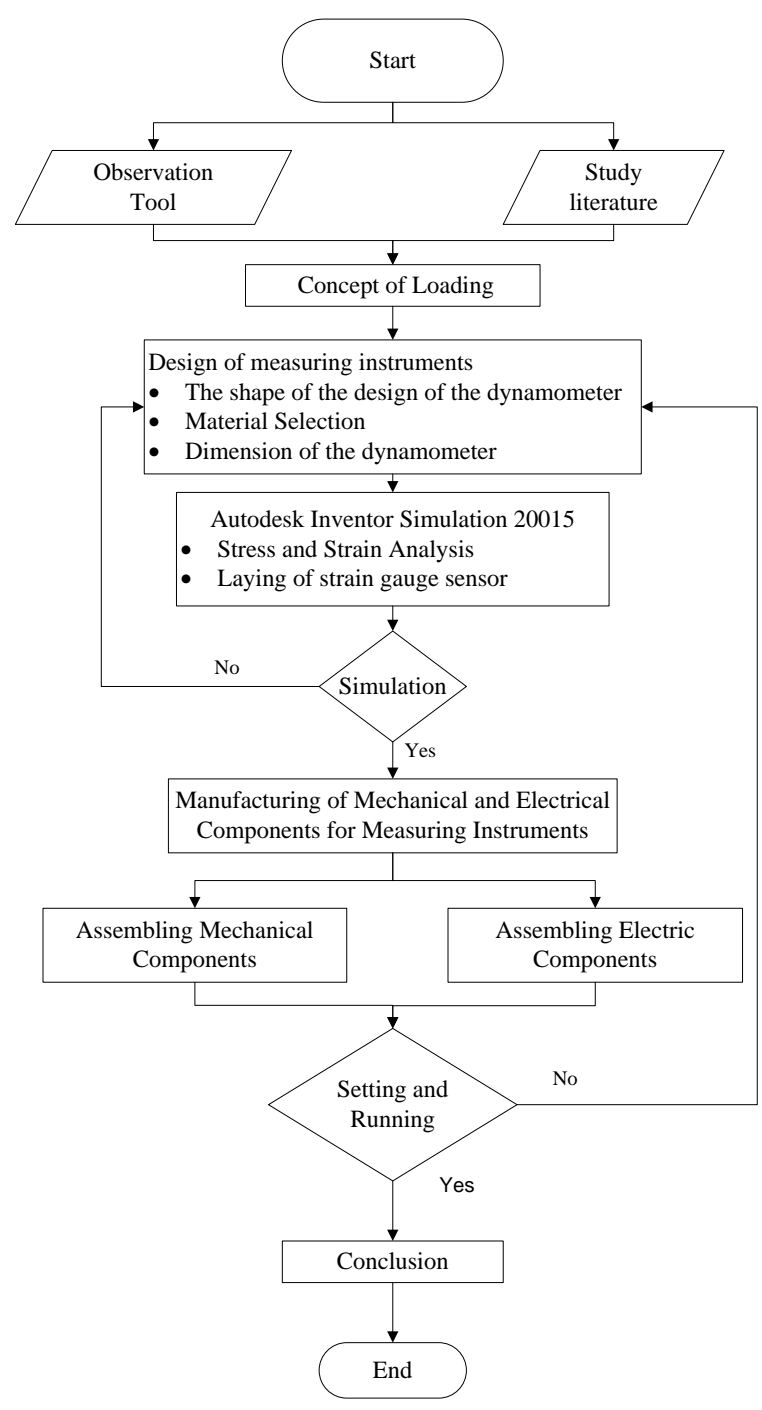

Figure 11: Methodology Flow Chart

\subsection{Observation and Literature}

Tool observations were made to determine the placement of the dynamometer on a rotary friction welding machine. While the literature study is conducted to look for theoretical references related to research.

\subsection{Concept of Loading}

At this stage the dynamometer is mounted on the four bolts located on the frame of the electric motor itself. When the electric motor rotates (torque) and the pull of the v-belt, the frame or leg of the electric motor experiences a tensile press. Then the dynamometer as a sensor rod must be able to read the axial force due to the pull of the v-belt that occurs in each pedestal. With known axial loading, it can determine the type of chain or wheastone bridge that is capable of blasting force when the electric motor does the welding process.

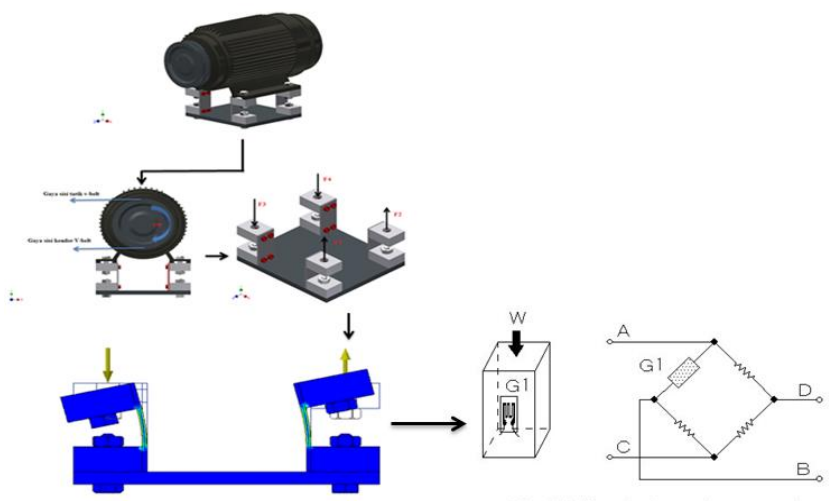

Figure 12: Concept of Loading

\subsection{Tool Design}

The design of the dynamometer is based on the size of the footprint of an electric motor that has four dynamometers. With long dimensions on the dynamometer are $35 \mathrm{~mm}, 45 \mathrm{~mm}$ and 70 $\mathrm{mm}$ high stem stretch. Specifically for the loading area of the rod the dynamometer is adjusted to the length of the bolts and nuts used. The bolts used are M8 x 30 hexagonal bolts.
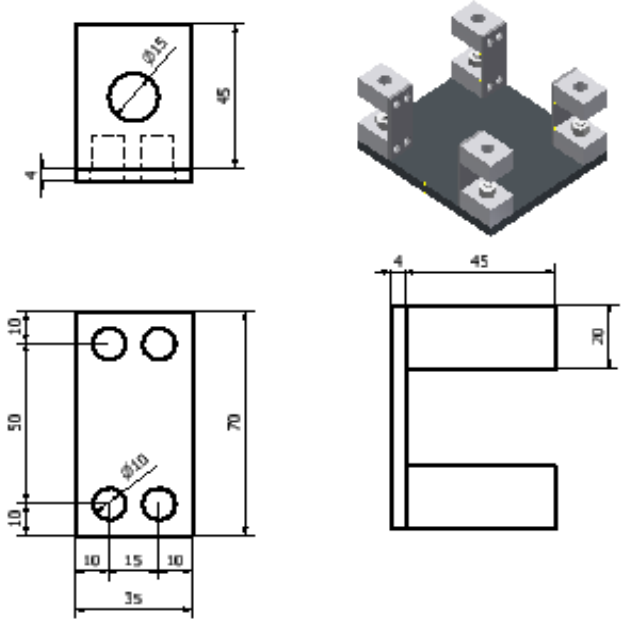

Figure 13: Tool Design

\subsection{Material Selection}

Material selection is an important thing in this research. In the selection of materials using the digital logic table method is a method that provides assessments, decisions, prices and material candidates that will be selected based on research that has been done other than that the material used must also meet the criteria of resistance to corrosion and easy machining process therefore Aluminum 6061 material has suitable criteria in making dynamometers and selected in the digital logic method.

\subsection{Strain Analysis on Dynamometers}

The parameters used in the analysis are as follows:

a. The dynamometer supports using a clump of flops.

b. The dynamometer material used is according to the material in the material selection. 


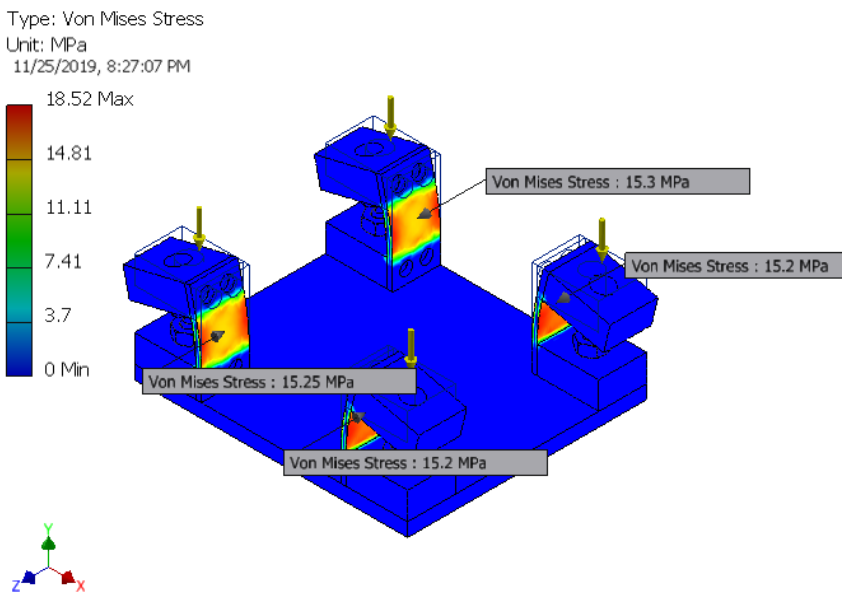

Figure 14: Simulation Results with Inventor

Figure 14. Explain the stresses that occur in the stem section of the dynamometer strain, the value of the critical stress experienced by the dynamometer with a maximum value of 15.25 $\mathrm{MPa}$. While the yield strength for the dynamometer strain rod material is $276 \mathrm{MPa}$, so the dynamometer still experiences elastic deformation because the stress that occurs in the stretch bar is smaller than the yield strength stress. So that the dynamometer size is designed according to and suitable for research.

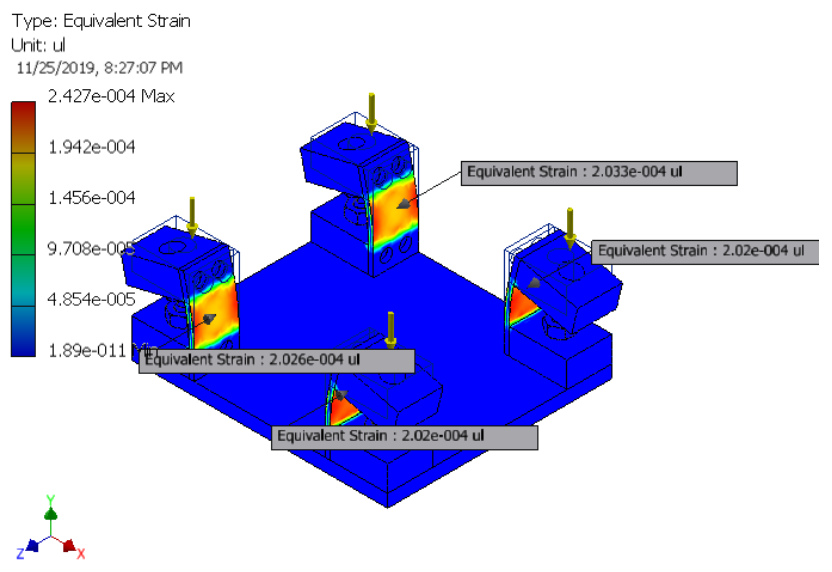

Figure 15: Hasil Simulasi Equivalent Strain

Figure 15. Explain the installation position and use of the strain gauge sensor is determined from the sensor reading range. Based on the 120 Ohm strain gauge specification data the strain level must not exceed $1500 \mu \varepsilon$. The simulation results in Figure 4.2 show a maximum deflection of $203.3 \mu \varepsilon$ (axial). It means that the position of the $120 \mathrm{ohm}$ strain gauge sensor is still within the range of strain range and strain level in the specification.

\subsection{Assembling Dynamometer}

This component is divided into two parts, namely the mechanical component used to read the strain and the electrical component that functions to change the strain received on the mechanic. a. Mechanical components

The mechanical component is made by frais machine and lathe. Square shape with dimensions of $70 \mathrm{~mm}$ x $35 \mathrm{~mm}$ and bolted the loading area so that the connection is not loose.

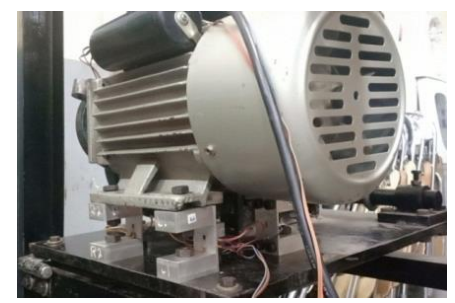

Figure 16: Mechanical Components of Dynamometer

b. Electrical components

Electrical components to read the strain that occurs on the strain rod and produce the output in newton units.

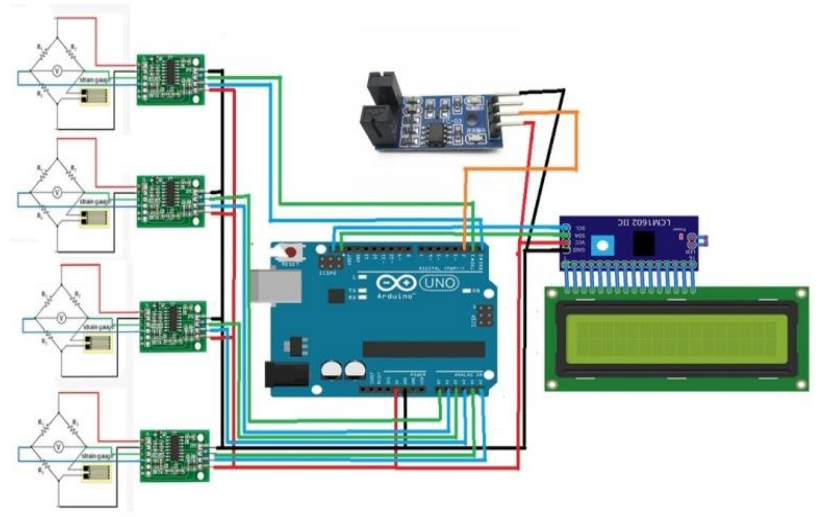

Figure 17: Electrical components

\subsection{Dynamometer Calibration}

The calibration process is used to convert from voltage to force. The calibration process of a dynamometer uses aids in the form of a vise so that the dynamometer can be calibrated axial directions.

\subsection{Set Up}

Components of the dynamometer (sensor rod) are installed under the foot of the electric motor. When an electric motor does welding, the dynamometer experiences a pull and pressure due to torque, v-belt pull and the weight of the motor so that it will cause strain changes on the sensor rod, so that there is a change in the resistance value on the strain gauge sensor. The strain is read by a strain gauge sensor which is assembled using a wheatstone bridge circuit, because the output value on the wheatstone bridge is still in the form of a voltage (volts) and the output value is still too small, then the HX711 Module (Amplifier) which is a weighing module and in it there is an Analog to Digital Converter (ADC) will automatically change the voltage value (volts) into grams. All electrical components are controlled by the Arduino program. The program is uploaded to Arduino from a computer using Arduino software. Then the results of the measurement values are displayed on the LCD and recorded using a Data Logger. Can be seen in figure 18 . 


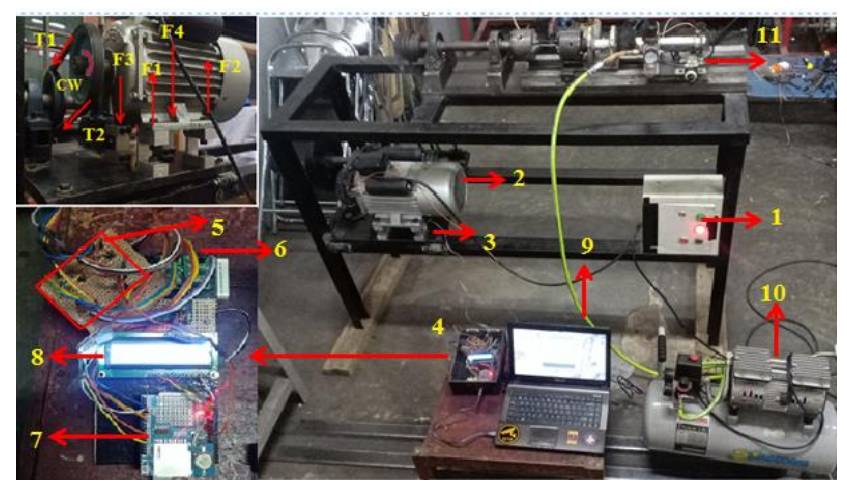

Caption:

1. Control Unit

2. Electric Motors

3. Dynamometer and Strain Gauge

4. Electrical Circuits

5. Wheatstone Bridge Series

6. Module HX-711

Figure 18: Testing scheme

\subsection{RESULT AND DISCUSSION}

\subsection{Test Result}

After conducting the experiment, the measurement results obtained as below.



Figure 19: Graph of Torque vs Times

It can be seen in the graph that from the first second of the initial rotation of the motor to the final stage of welding the torque value has increased. That is because the welding process is always given the addition of pneumatic pressure. In accordance with the process of taking data the sequential pneumatic pressure stage is 2 bars at constant rotation, 4 bars in the friction process and 6 bars in the forging process. So the greater the pneumatic pressure exerted on rotary welding, the rotary motor drive welding machine will experience an increase in the value of torque.

As for the motor rotational speed, it can be seen in Figure 19 displayed a graph of the calculation of the angular speed versus time ratio. In contrast to torque, the rotating speed of the rotary motor drive motor has decreased in the welding process.

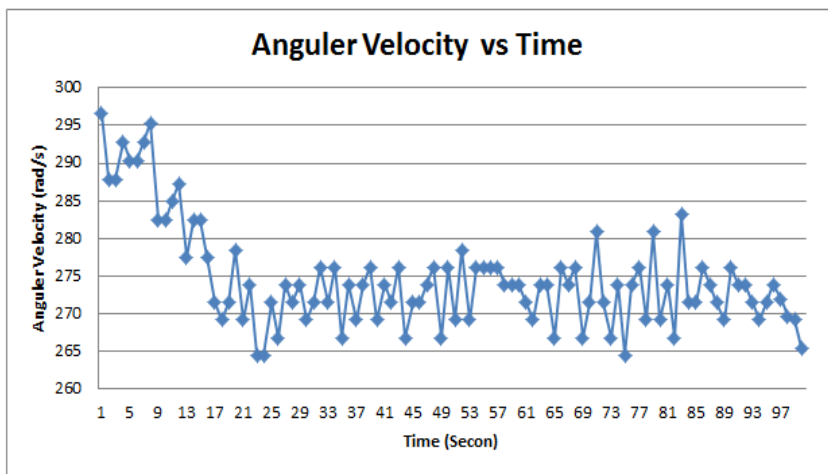

Figure 20: Graph of Motor Angular Speed vs Times



Figure 21: Graph \% Error Speed Angle vs Times

If the effective rotating speed of the motor used is $2800 \mathrm{Rpm}$ or $293.21 \mathrm{rad} / \mathrm{s}$, then to determine the difference in value or $\%$ Error the measured rotational speed during welding with the effective motor rotational speed value used by the following equation.

$$
\% \text { Error } \omega=\left[\frac{\omega_{\text {efektif }}-\omega_{\text {terukur }}}{\omega_{\text {efektif }}}\right] x 100 \%
$$

The biggest \% Error $\omega$ value is the last second when forging is $9.46 \%$, due to the angular speed of the motor when the forging slows down.

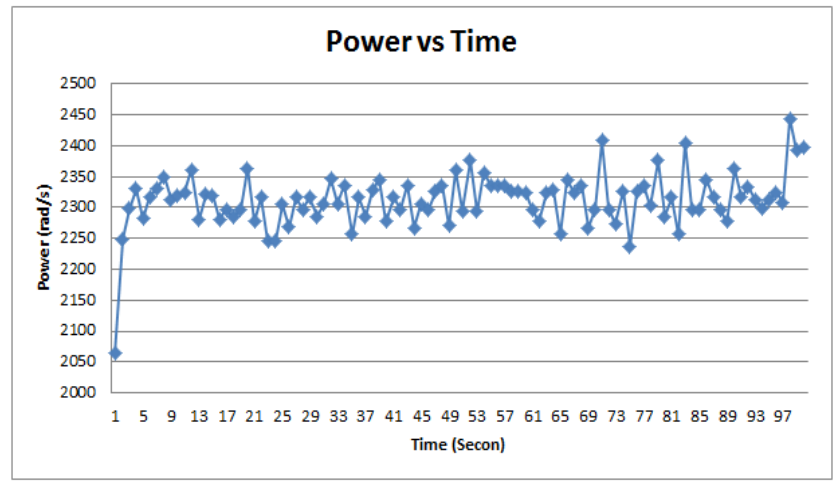

Figure 22: Graph of Power vs Times 
In Figure 22, a graph showing the calculation of the time comparability as well as the torque conditions, that the power from the initial rotation to the final stage of welding increases in value. It can be interpreted that the greater the pneumatic pressure exerted when welding, the measured power is also greater.

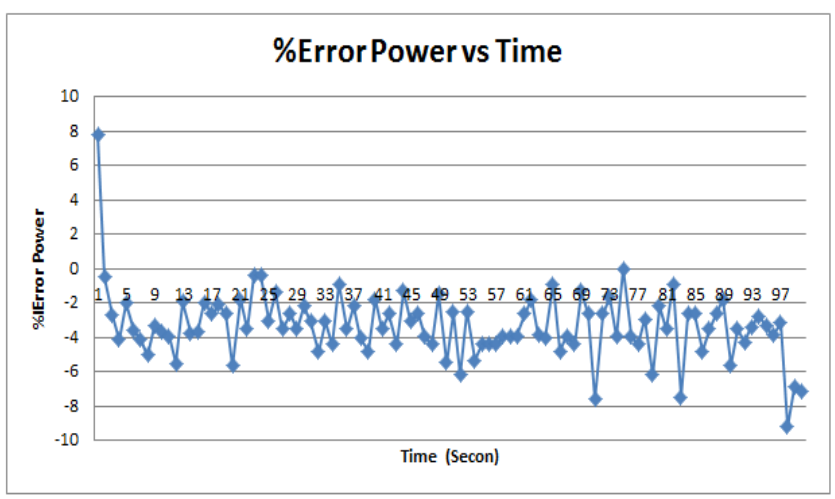

Figure 23: Graph of \% Error Power vs Times

If the effective power of the motor used is $3 \mathrm{Hp}$ or 2238 watts, it is necessary to determine the difference in value or\% Error measured power during welding with the effective power of the motor used in the following equation.

$$
\text { \% Error } P=\left[\frac{P_{\text {efektif }}-P_{\text {terukur }}}{P_{\text {efektif }}}\right] x 100 \%
$$

and \% Error $\mathrm{P}$ is when forging equal to $-7.09 \%$, because \% Error is absolute, the value is considered positive.

\subsection{CONCLUSION}

From the research that has been done, it can be concluded.

a. The stretch bar serves as a torque gauge by using a $120 \mathrm{ohm}$ strain gauge and the dimensions of the dynamometer as the stretch bar are $35 \mathrm{~mm}$ long, 45 wide, 70 high and $4 \mathrm{~mm}$ thick.

b. Making an electrical circuit that functions as a microcontroller that can read the change in resistance of the strain gauge sensor due to flexural stem deflection and the value measured by the optocoupler sensor (rpm sensor) into a digital number that can be displayed on the LCD.

c. The largest measured power value is 2408.50 Watts and the smallest power measured in the initial rotation is 2050.24 Watts.

\section{REFERENCE}

1. Khan, M.A dan Alhadi, R. 2014. Perancangan Dan Pembuatan Mesin Las Gesek Rotari. Skripsi. Program Studi Diploma Tiga Teknik Mesin Universitas Riau.

2. Ricky dan Yohanes. 2015. Redesign Alat Las Gesek Rotari dengan Pendekatan Fault Tree Analysis (FTA) dan Design for Manufacture and Assembly (DFMA). Jom F-TEKNIK. Vol 5.
3. Yohanes, P. Partomuan dan Sunaryo. 2016. Pengaruh Bentuk Permukaan Forging Sambungan Las Gesek Rotary Terhadap Kekuatan Tarik Baja Mild Steel.Jurnal Simposium Nasional Teknologi Terapan. 4:509-517.

4. Yohanes dan Siregar, E. 2017. Experimental Study Influence Of Flywheel Addition On Drive System Rotary Friction Welding For Result Welding. Vol 52:14-19.

5. Sandri, D. E, dan Yohanes. 2018. Studi Eksperimental Pengaruh Penambahan Flywheel Pada Sistem Penggerak Mesin Las Gesek Rotari Terhadap Hasil Pengelasan Material Mild Steel Dengan Stainless Steel 201. Jom FTEKNIK. Vol 5.

6. Yohanes, dan M. Efriansyah. 2018. Influence of Flywheel for Drive System of Rotary Friction Welding and Chamfer Angle Variations Forging to Welding Strength. Proceeding of Ocean, Mechanical and Aerospace -Science and Engineering-.Vol5. No1.

7. Prasetyono, S dan Subiyanto. H. 2012. Pengaruh Durasi Gesek, Tekanan Gesek Dan Tekanan Tempa Terhadap Impact Strength Sambungan Lasan Gesek Langsung Pada Baja Karbon Aisi 1045. Jurnal Sains Dan Seni Pomits. Vol. 1, No. 1, 1-5.

8. Indian institute of technology kharagpur. 2011. Dynamometer for measuring cutting force. India.

9. Sularso dan S. Kiyokatsu. 2005. Dasar Perencanaan Dan Pemilihan Elemen Mesin. Pradnya Paramita. Jakarta.

10. Figliola, R.S. dan. D.E. Beasley. 2011. Theory and Design for Mechanical Measurement. Edisi 5. John Willey \& Sons. Inc. New Jersey.

11. Ichwan, M. M.G. Husada. M.I. Ar Rasyid. 2013. Pembangunan Prototipe Sistem Pengendalian Peralatan Listrik Pada Platform Android. Jurusan Teknik Informatika. Institut Teknologi Nasional Bandung.

12. Lingga, W. 2006. Belajar Sendiri Mikrokontroler AVR Seri ATMega 32 Simulasi, Hardware, Aplikasi. Andi Offset Yogyakarta. 